ARAŞTIRMA / RESEARCH

\title{
Relationship of blood 25-hydroxy vitamin D level with fibrocystic breast disease and breast density
}

Kan 25-hidroksi D vitamini düzeyinin fibrokistik meme hastalığ1 ve meme yoğunluğu ile ilişkisi

\section{Hacı Bolat 1 (iD, Alirıza Erdoğan ${ }^{1}$ (D)}

${ }^{1}$ Niğde Ömer Halisdemir University, School of Medicine, Department of General Surgery

$$
\text { Cukurova Medical Journal 2022;47(1):161-168 }
$$

\section{Abstract}

Purpose: The aim of this study is to evaluate the association of blood 25-hydroxy vitamin D levels with fibrocystic breast masses and breast patterns.

Materials and Methods: The study included 612 patients who presented with breast complaints or referred for routine screening between 2018-2021 and were requested to have breast ultrasonography (USG) and mammography (MG) examinations. Patients were divided into two groups; group 1 consisted of women with fibrocystic mass (BI-RADS 2-3) and group 2 consisted of women without breast mass (BI-RADS 1). These two groups were compared by age, breast USG, MG results, and blood 25hydroxy vitamin D levels.

Results: Of the 612 patients, 310 (51\%) had fibrocystic mass in their breasts, while $302(49 \%)$ had normal breasts. The mean age of both groups was similar. Those with fibrocystic mass in the breast had lower vitamin D levels and higher breast density than the control group. The group with higher breast density had lower vitamin D levels, and there was a negative correlation between vitamin $\mathrm{D}$ level and breast density

Conclusion: Our study revealed that women with fibrocystic masses in their breasts (BI- RADS2 and BIRADS3) had higher breast density and lower vitamin D levels than women without breast mass.

Keywords:. Fibrocystic breast masses, breast density, vitamin D
Öz

Amaç: Bu çalışmanın amacı kan 25-hidroksi D vitamin seviyesinin memenin fibrokistik kitleleri ve meme paternleri ile olan ilişkisini değerlendirmektir.

Gereç ve Yöntem: Çalışmaya 2018-2021 yılları arasında meme şikayeti veya rutin tarama için başvuran, meme ultrasonografi (USG) ve mamografi (MG) tetkiki istenen 612 hasta dahil edildi. Memede fibrokistik kitlesi olanlar (BI-RADS 2-3) grup 1 ve memede kitlesi olmayanlar (BIRADS 1) grup 2 olmak üzere hastalar iki gruba ayrıldı. Her iki grup; yaş, meme USG, MG sonuçları ve kan 25-hidroksi D vitamin seviyeleri açısından karşılaştırıldı.

Bulgular: Çalışmaya dahil edilen kadınların 310 (\%51)'da memede fibrokistik kitle tespit edilirken, $302(\% 49)$ 'sinin memesi normaldi. Her iki grubun yaş ortalaması benzerdi. Memede fibrokistik kitlesi olanların kontrol grubuna göre $\mathrm{D}$ vitamin seviyesi daha düşük ve meme yoğunluğunun daha fazla olduğu tespit edildi. Meme yoğunluğu fazla olan grubun az olan gruba göre D vitamini seviyesinin daha düşük olduğu ve $\mathrm{D}$ vitamin seviyesi ile meme yoğunluğu arasında negatif korelasyon olduğu bulundu.

Sonuç: Çalışmamızda memesinde fibrokistik kitlesi (BIRADS2 ve BI-RADS3) olan kadınlarda, memesinde kitle olmayan kadınlara göre meme yoğunluğunun daha fazla ve $\mathrm{D}$ vitamini seviyesinin daha düşük olduğu bulundu.

Anahtar kelimeler: Memenin fibrokistik kitlesi, meme yoğunluğu, D vitamini 


\section{INTRODUCTION}

Breast masses constitute a concern for patients and physicians since breast cancer is the most common cancer in women. Fortunately, the majority of breast masses are benign ${ }^{1}$. The most common benign breast masses are fibrocystic breast masses $(\mathrm{FBM})^{2}$. Gopalani et al. reported that fibrocystic breast changes are most common in women between the ages of $30-50$, and $30-60 \%$ of women of all ages may have a fibrocystic mass in the breast ${ }^{3}$. Estrogen and progesterone change cyclically with each menstrual cycle. Since the breast is one of the target organs for estrogen and progesterone, it is exposed to the effects of these hormones in each menstrual cycle. During these cyclical fluctuations, unusual changes occurring in the stroma, milk ducts, and lobules of the breast have been suggested to cause $\mathrm{FBM}^{4}$. Hyperestrogenism and anovulation are also considered among the main causes of FBM development ${ }^{5}$. Women with FBM often present with the complaint of a mass and physical examination usually reveals a painless, smooth mass with discrete borders $^{6}$. The mass is classified into 3 subgroups histopathologically; hyperplastic fibrous cyst, adenosis, and papillomatosis ${ }^{7}$. In addition to physical examination, ultrasonography and mammography are frequently used as imaging modalities in the diagnosis of $\mathrm{FBM}^{2}$. They are the most common methods for screening breast masses The parenchymal structure of the breast and the detected pathological conditions are characterized by the Breast Imaging Reporting and Data System (BI-RADS) classification system ${ }^{8}$. Benign and malignant lesions of the breast can be categorized more easily with BI-RADS classification?. BI-RADS classification system enables the categorization of images obtained by ultrasonography (USG) and mammography (MG) into seven main categories numbered 0 to 6 . BI-RADS 0 indicates masses requiring additional imaging, BI-RADS 1 indicates normal breast, BI-RADS 2-3 indicates benign masses, BI-RADS 4 indicates masses with suspected malignancy, BI-RADS 5 indicates masses with high suspicion of malignancy and BI-RADS 6 indicates masses with known biopsy-proven malignancy ${ }^{10}$. Additionally, BI-RADS classification also classifies 4 categories of fibroglandular density patterns described as almost entirely fatty (ta), scattered fibroglandular density (tb), heterogeneously dense (tc), and extremely dense (td) ${ }^{11}$. Mammographic breast density is a reflection of the amount of epithelial and stromal tissue in the breast, and high breast density is one of the strongest predictors of breast cancer risk ${ }^{12}$.

Serum Vitamin D levels have been reported to be below the normal limit in approximately one billion people indicating that Vitamin D deficiency is a widely prevalent health hazard worldwide ${ }^{13}$. The importance of vitamin D, long-known for its crucial role in calcium homeostasis, and bone metabolism, is better understood recently by subsequent publication of several studies demonstrating the association of vitamin $\mathrm{D}$ levels with many organ cancers, heart disease, diabetes mellitus, and fertility rates ${ }^{14,15}$. It has long been speculated that vitamin D deficiency would accelerate the cellular proliferation of breast tissue in women and lead to the formation of breast masses ${ }^{16}$. Garland et al demonstrated a relation between serum vitamin D levels and breast cancer in 2007 which accelerated the studies on this subject subsequently. They reported a relative risk of $50 \%$ increase in women with serum Vitamin D levels $\leq 13 \mathrm{ng} / \mathrm{ml}$ when compared to women with serum Vitamin D levels $\geq 52 \mathrm{ng} / \mathrm{ml}$ for breast cancer ${ }^{17}$.More recently, experimental and clinical studies of Lopes et al. revealed that normal levels of vitamin $\mathrm{D}$ may play a role in preventing the formation of malignant masses of the breast ${ }^{18}$.

The aim of this study is to evaluate the relationship of serum Vitamin D levels with fibrocystic masses and breast pattern.

\section{MATERIALS AND METHODS}

Women who applied to Niğde Ömer Halisdemir University Medical Faculty Training and Research Hospital General Surgery Clinic between January 2018 and January 2021 for breast disease or for routine breast screening were retrospectively evaluated. The study was conducted in accordance with the principles of the Declaration of Helsinki, after receiving approval from the ethics committee of Niğde Ömer Halisdemir University (date: 12.08.2021, number: 2021/73).

\section{Study population}

Women who underwent breast USG and MG imaging and also had their vitamin $\mathrm{D}$ levels checked within the last 1 month before the date of admission were enrolled to the study. Patients whose 25Hydroxy vitamin D levels were not checked in the last month, who took oral 25 -Hydroxy vitamin D supplements in the last 1 year, aged under 35 or over 
80 years, have a malignant or suspicious mass in the breast, have a solid mass such as fibroadenoma and lipoma in the breast, had breast surgery for any reason, have mastitis, and classified BI-RADS 4, 5, 6 on USG and MG were excluded from the study.

Among 612 patients who underwent breast USG and MG after a physical examination, 310 patients with a fibrocystic breast mass constituted the study group, and 302 patients with no breast pathology formed the control group.

Further the study population was divided as study group and control group. The study group included women aged $35-80$ years who applied to the general surgery outpatient clinic for control purposes or due to a complaint of a breast mass and diagnosed with a fibrocystic breast mass classified as BI-RADS 2-3 on breast USG and BI-RADS 0-2-3 on MG. The control group included women aged 35-80 years who applied to the general surgery outpatient clinic for control purposes or with breast pain or the suspicion of a breast mass and were classified as BI-RADS1 category on breast USG and MG. Exclusively, both groups included patients whose blood 25-Hydroxy vitamin $\mathrm{D}$ levels were checked in the last 1 month before the date of admission.

\section{Technical description of variables}

Patient information regarding age and serum 25Hydroxy-vitamin D levels of the individuals who met the study criteria were retrieved from the computerbased electronic archive system of our hospital and recorded. The presence of a mass in the breast USG and MG reports, its category in the BI-RADS classification, the diameter of the detected mass, and the breast pattern (breast density) classification in MG were also recorded. Electrochemiluminescence immunoassay analysis used to measure vitamin D levels and the reference range was $20-100 \mathrm{ug} / \mathrm{ml}$.

\section{Statistical analysis}

For power analysis calculations $G^{*}$ Power 3.1 (ref; Faul et al. 2007, Erdfelder et al. 2009) was used. A posthoc power analysis was conducted to test the difference between two independent group means using a two-tailed test, a strong effect size $(\mathrm{d}=0.80)$, and an alpha of 0.05 . Result showed that a total sample of 612 participants (310 study group and 302 control group) for diagnosis achieve a power of 1.0019,20.

The descriptive statistics were expressed as mean $\pm \mathrm{SD}$ for continuous variables and as $\%$ (range) for categorical variables. The confidence intervals (95\% C.I) were expressed in tables for VAS scores. The normality of the variables was tested by ShapiroWilk test. USG BI-RADS categories were analysed using the Pearson Chi-square test. Age, serum vitamin D levels and cyst diameter were compared with the Student's t-test. MG BI-RADS categories and breast patterns were compared by using OneWay-ANOVA test. For posthoc analysis LSD was used to test the differences between the groups. Spearman correlation coefficient was used in the non-parametric correlation test of breast patterns and serum vitamin D levels. In order to calculate the Spearman's Rho for ordinal variables, Vitamin D levels were converted to ordinal values $(\leq 13 \mathrm{ng} / \mathrm{ml}$, $13-52 \mathrm{ng} / \mathrm{ml}, \geq 52 \mathrm{ng} / \mathrm{ml}$ ) according to cut-off values proposed by Garland et al ${ }^{17}$. SPSS 22.0 (SPSS, Inc, Chicago, IL, A.B.D.) software was used for statistical calculations and a $p<0.05$ was considered statistically significant.

\section{RESULTS}

A total of 612 patients, 310 with breast cysts and 302 without breast cysts, were examined in the study. The descriptive characteristics of the study and control groups are shown in Table 1. There was no significant age difference between the study and control groups $(\mathrm{p}=0.787)$.

Vitamin D levels in women with breast cysts were significantly lower than the control group $(17.53 \pm 0.70 \mathrm{IU} / \mathrm{ml} ; 95 \%$ CI $16.14-18.91$ and $24.87 \pm 0.73 ; \quad 95 \% \quad$ CI $23.42-26.31 ; \quad \mathrm{p}<0.0001$, respectively). The groups were significantly different in the distribution of 4 different breast patterns $(p<0.0001)$. The percentages of women with USG and MG BI-RADS categories and localization of the breast mass in women with cysts are shown in Table 2.

Vitamin D levels by USG and MG BI-RADS categories are shown in Table 3. According to the USG BI-RADS classification in patients with cysts, the vitamin $\mathrm{D}$ levels were significantly higher in women with BI-RADS 2 than with BI-RADS 3 $(p<0.0001)$. Similarly, women with mammographic BI-RADS 3 had statistically lower vitamin D levels than women with BI-RADS $2(\mathrm{p}<0.0001)$. Vitamin D levels according to breast pattern in the study and control groups are shown in Table 4. In both groups, Vitamin D levels were significantly different in each breast pattern. Post hoc analyses ascertained that 
vitamin $\mathrm{D}$ levels were statistically different in each of the 4 breast patterns in the study group $(\mathrm{p}<0.0001$ for BI-RADS 2 and BI- RADS 3 categories, $p=0.252$ for BI-RADS 0 and BI-RADS 2 categories, $\mathrm{p}=0.78$ for BI-RADS 0 and BI-RADS 3). The correlation between breast pattern and vitamin $\mathrm{D}$ level in both groups is shown graphically in Figure 1. There was a moderate negative correlation between breast patterns and vitamin $\mathrm{D}$ levels in both study groups (Spearman's rho $=-0.338, \mathrm{p}<0.0001$ in control group and Spearman's rho $=-0.424, \mathrm{p}<0.0001$ in study group).

Table 1. Descriptive characteristics and vitamin D levels of the study groups

\begin{tabular}{|c|c|c|c|c|c|c|c|}
\hline & \multicolumn{2}{|c|}{ Total } & \multicolumn{2}{|c|}{ Study Group } & \multicolumn{2}{|c|}{ Control Group } & \\
\hline & mean \pm S.E.*** & $95 \%$ C.I. $* * * *$ & mean \pm S.E & $95 \%$ C.I. & mean \pm S.E & $95 \%$ C.I. & $p$ \\
\hline Age & $47.44 \pm 0.36$ & $46.72-48.16$ & $46.13 \pm 0.43$ & $45.27-46.98$ & $46.28 \pm 0.58$ & $45.64-47.93$ & 0.787 \\
\hline $\begin{array}{l}\text { Cyst diameter* } \\
(\mathrm{mm})\end{array}$ & $5.53 \pm 0.30$ & $4.93-6.12$ & $10.93 \pm 0.41$ & $10.12-11.74$ & 0 & 0 & \\
\hline $\begin{array}{l}\begin{array}{l}\text { Vitamin D } \\
(\mathrm{IU} / \mathrm{ml})\end{array} \\
\end{array}$ & $21.15 \pm 0.53$ & $20.12-22.19$ & $17.53 \pm 0.70$ & $16.14-18.91$ & $24.87 \pm 0.73$ & $23.42-26.31$ & $<0.0001$ \\
\hline **Pattern & $\mathrm{n}$ & $\%$ & $\mathrm{n}$ & $\%$ & $\mathbf{n}$ & $\%$ & $p$ \\
\hline ta & 10 & 1.6 & 3 & 1.0 & 7 & 2.3 & \\
\hline $\mathrm{tb}$ & 246 & 40.1 & 92 & 29.7 & 154 & 50.8 & 1 \\
\hline tc & 285 & 46.5 & 170 & 54.8 & 114 & 38 & -0.0001 \\
\hline $\mathrm{td}$ & 72 & 11.7 & 45 & 14.5 & 27 & 8.9 & \\
\hline
\end{tabular}

*Maximum diameter, **Pattern: Fatty (ta), scattered fibroglandular density (tb), heterogeneously dense (tc), and extremely dense (td) $* * *$ S.E:Standard error, ${ }^{* * * *}$ C.I.:Confidence interval

Table 2. Ultrasonographic and mammographic BI-RADS categories and localization of the breast mass in women with cysts

\begin{tabular}{|l|c|c|}
\hline Localization & $\mathbf{n}$ & $\mathbf{\%}$ \\
\hline Unilateral & 99 & 31.9 \\
\hline Bilateral & 211 & 68.1 \\
\hline USG *BI-RADS & $\mathrm{n}$ & $\%$ \\
\hline 1 & 0 & 0 \\
\hline 2 & 171 & 55.2 \\
\hline 3 & 139 & 44.8 \\
\hline Mammography *BI- RADS & $\mathrm{n}$ & $\%$ \\
\hline 0 & 5 & 1.6 \\
\hline 2 & 159 & 51.3 \\
\hline 3 & 146 & 47.1 \\
\hline
\end{tabular}

*BI- RADS: Breast Imaging Reporting and Data System

Table 3. Vitamin D levels in women with breast cysts according to ultrasonographic and mammographic BIRADS classification

\begin{tabular}{|c|c|c|c|}
\hline USG BI-RADS & Mean \pm S.E** & $95 \%$ C.I. $* * *$ & $\mathrm{p}$ \\
\hline 2 & $20.88 \pm 1.14$ & $18.63-23.13$ & \multirow[b]{2}{*}{$<0.0001$} \\
\hline 3 & $13.39 \pm 0.53$ & $12.36-14.44$ & \\
\hline $\begin{array}{l}\text { Mammography } \\
\text { *BI- RADS } \\
\end{array}$ & Mean \pm S.E.** & $95 \%$ C.I. $* * *$ & $\mathrm{p}$ \\
\hline 0 & $15.07 \pm 1.85$ & $9.92-20.23$ & \multirow[b]{3}{*}{$<0.0001 * * * *$} \\
\hline 2 & $21.24 \pm 1.21$ & $18.83-23.64$ & \\
\hline 3 & $13.57 \pm 0.51$ & $12.55-14.59$ & \\
\hline
\end{tabular}

*BI- RADS: Breast Imaging Reporting and Data System, ${ }^{* *}$ S.E:Standard error, ${ }^{* * *}$ C.I.:Confidence interval, ${ }^{* * * *}$ Post Hoc analysis (LSD) $\mathrm{p}$-value was calculated as $\mathrm{p}<0.0001$ between BI-RADS 2 and BI- RADS 3 categories. BI-RADS 0 and BI-RADS $2 \mathrm{p}=0.252$; BI-RADS 0 and BI-RADS $3 \mathrm{p}=0.78$. 
Table 4. Vitamin D levels according to breast pattern in the study and control groups

\begin{tabular}{|c|c|c|c|c|c|c|}
\hline \multirow{2}{*}{$\begin{array}{l}\text { *Breast } \\
\text { Pattern }\end{array}$} & \multicolumn{3}{|c|}{ Study Group } & \multicolumn{3}{|c|}{ Control Group } \\
\hline & Mean \pm S.E** & $95 \%$ C.I. $* * *$ & $p$ & Mean \pm S.E & $95 \%$ C.I. & $p$ \\
\hline ta & $65.86 \pm 12.06$ & $13.94-117.78$ & $<0.0001^{* * * *}$ & $23.37 \pm 2.59$ & $17.01-29.73$ & $<0.0001 \bullet$ \\
\hline tb & $23.73 \pm 1.47$ & $20.81-26.65$ & & $27.67 \pm 1.01$ & $25.66-29.68$ & \\
\hline tc & $14.95 \pm 0.7$ & $13.56-16.33$ & & $23.92 \pm 1.17$ & $21.59-26.24$ & \\
\hline $\mathrm{td}$ & $11.36 \pm 0.68$ & $9.98-12.74$ & & $13.28 \pm 1.43$ & $10.34-16.21$ & \\
\hline
\end{tabular}

*Breast Pattern: Fatty (ta), scattered fibroglandular density (tb), heterogeneously dense (tc), and extremely dense (td), ${ }^{* * S . E: S t a n d a r d ~ e r r o r ; ~}$ $* * *$ C.I.:Confidence interval, $* * * *$ Post Hoc analysis (LSD) p-values were calculated as; $\mathrm{p}<0.0001$ between ta and tb; $\mathrm{p}<0.0001$ between ta and tc, $\mathrm{p}<0.0001$ between ta and td, $\mathrm{p}<0.0001$ between tb and tc, $\mathrm{p}<0.0001$ between tb and td, and $\mathrm{p}=0.043$ between tc and td.;

Post Hoc analysis (LSD) p-values were calculated as; $\mathrm{p}=0.36$ between ta and tb, $\mathrm{p}=0.908$ between ta and tc, $\mathrm{p}=0.051$ between ta and td, $\mathrm{p}=0.013$ between tb and tc, $\mathrm{p}<0.0001$ between tb and $\mathrm{td}$, and $\mathrm{p}<0.0001$ between tc and $\mathrm{td}$.

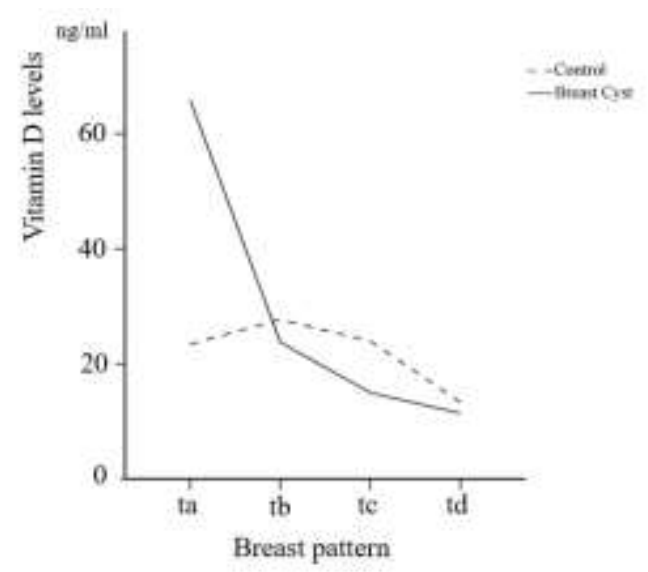

Figure 1. Correlation between breast patterns and vitamin D levels.

(Spearman's rho $=-0.338, \mathrm{p}<0.0001$ in control group and Spearman's rho $=-0.424, \mathrm{p}<0.0001$ in study group).

\section{DISCUSSION}

Of the 612 patients included in the study, 51\% had a fibrocystic mass in their breasts, while physical examination and imaging methods detected no pathological findings in $49 \%$. While the age and gender of patients in both groups were similar, the Vitamin D level of the group with BI-RADS 0, BIRADS 2, and BI-RADS 3 was significantly lower women with BI-RADS1. In the study group, the Vitamin D levels of BI-RADS 3 patients were significantly lower than those of BI-RADS 2 patients. In addition, there was a negative correlation between the patients' breast fibroglandular density (pattern) and Vitamin D levels.
Nielsen et al. reported a strong relationship between breast cancer and fibrocystic masses of the breast in their study involving 84 female patients ${ }^{21}$. Sappino et al. showed in their experimental studies on mice that changes in stromal cells seen in malignant masses of the breast are also observed in fibrocystic diseases, suggesting a possible relationship between fibrocystic diseases and breast cancers ${ }^{22}$. Studies have reported that vitamin $\mathrm{D}$ levels are low in many cancers, especially breast cancer ${ }^{23}$. Welsh pointed out that vitamin D receptor is highly expressed in the glandular tissue of the breast, and vitamin D deficiency is common in patients with breast cancer ${ }^{24}$. Furthermore, Hatun et al. reported that vitamin D reduces the possibility of breast cancer and positively affects the prognosis of patients with breast cancer, and suggested the use of vitamin $\mathrm{D}$ preparations in the prevention and treatment of breast cancer ${ }^{25}$. In vitro studies have reported that by activating vitamin $\mathrm{D}$ receptors in mammary gland tissue, vitamin $\mathrm{D}$ slows down the cell cycle, increases cell death, and induces both apoptosis and autophagy ${ }^{26,27}$. Thus, it has been shown that the binding of vitamin $\mathrm{D}$ to its receptors suppresses various genes involved in mass formation, thereby slowing down cellular growth responsible for mass development ${ }^{28,29}$. The experimental studies of Bikle et al. demonstrated that fewer tumors were formed in the vitamin D group than in the control group, and vitamin D reduced the formation and growth of tumor cells by activating the tumor suppressor genes P21, P27, and P53 ${ }^{30}$. Another study reported that, besides preventing tumor formation and growth, vitamin D contributes to patient survival by slowing down tumor metastasis ${ }^{31}$. .However, a Mendelian randomization study of approximately 15000 breast cancer and 
22000 prostate cancer patients conducted by Jiang et al. reported that vitamin $\mathrm{D}$ had no effect on these cancer types ${ }^{32}$. Nevertheless, the most recent metaanalysis of 474 scientific articles reported that vitamin $\mathrm{D}$ deficiency is quite common among breast cancer patients compared to the normal population, and therefore, it can be given for preventive purposes against breast cancer ${ }^{33}$.

Although malign masses were not evaluated in this study, high breast pattern and fibrocystic masses were reported to be associated with malignant transformation previously ${ }^{21}$. Our results define a significantly lower levels of serum vitamin $\mathrm{D}$ in women with breast masses. Additionally, a moderate negative correlation between vitamin $\mathrm{D}$ levels and breast density was detected, which might further enhance the relation between vitamin $\mathrm{D}$ deficiency and malignant transformation.

Women with high breast density have more stromal and epithelial tissue and less adipose tissue in their breasts. Studies have shown that women with high breast density have a higher risk of developing breast cancer than women with low breast density ${ }^{34}$. It has been suggested that women with a breast density of $75 \%$ or more may be 4 to 6 times more likely to have breast cancer than women with little or no breast density ${ }^{35,36}$. In addition, clinical studies argued that high breast density might reduce the sensitivity of MG by concealing the masses in the breast and cause false-positive and false-negative results ${ }^{37,38}$. Besides, many studies have reported that high breast density may play a role in the development of benign and malignant masses in the breast, independent of other factors in the etiology $39,40,41$.

In a clinical study involving 300 women of different ethnicities with high breast density and vitamin D deficiency, raising the serum vitamin $\mathrm{D}$ levels to the normal range by giving vitamin $\mathrm{D}$ supplementation for 1 year did not have a significant effect on breast density ${ }^{42}$. Yet, a case-control study by Brisson et al. involving premenopausal women reported a decrease in breast density in the vitamin $\mathrm{D}$ group compared to the placebo group ${ }^{43}$. Duma et al., on the other hand, reported in their clinical studies that women with low vitamin $\mathrm{D}$ levels had higher breast density and higher incidence of breast masses than women with normal vitamin D levels ${ }^{44}$. Our study also detected a high rate vitamin $\mathrm{D}$ deficiency in women with high breast density. Similar to aforementioned studies the results of this study demonstrated that Vitamin D levels were consistently lower in women with breast masses as well as in women with high breast density.

The main limitation of our study is the retrospective design. Besides, the discrimination between premenopausal, perimenopausal or postmenopausal periods of women was not possible due to the retrospective design. On the other hand, its strength is being the first study to assess the association of vitamin $\mathrm{D}$ with fibrocystic breast disease of the breast and breast density in women.

Our study determined that women with fibrocystic mass in their breasts had higher breast density and lower vitamin $\mathrm{D}$ levels than individuals with normal breasts. This finding suggests that checking vitamin $\mathrm{D}$ levels in women and recommending vitamin $\mathrm{D}$ supplementation to those with low vitamin D levels may be beneficial in reducing breast density and mass formation in the breast, which are the etiological causes of breast cancer. These findings need to be supported by multicenter and prospective studies.

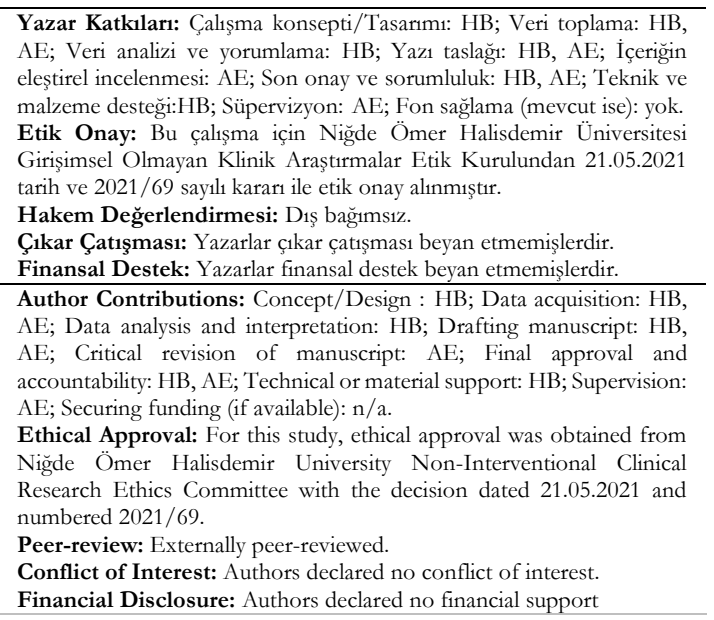

\section{REFERENCES}

1. Guray M, Sahin AA. Benign breast diseases: classification, diagnosis and management. Oncologist. 2006;11:435-49.

2. Talaei A, Moradi A, Rafiei F. The evaluation of the effect of metformin on breast fibrocystic disease. Breast Dis. 2017;37:49-53.

3. Gopalani S V, Janitz AE, Martinez SA, Gutman P, Khan S, Campbell JE. Trends in cancer incidence among American indians and Alaska natives and nonhispanic whites in the United States, 1999-2015. Epidemiology. 2020;31:205-13.

4. Ameen F, Reda SA, El-Shatoury SA, Riad EM, Enany ME, Alarfaj AA. Prevalence of antibiotic resistant mastitis pathogens in dairy cows in Egypt and 
potential biological control agents produced from plant endophytic actinobacteria. Saudi J Biol Sci. 2019;26:1492-8.

5. Lundberg FE, Iliadou AN, Rodriguez-Wallberg K, Gemzell-Danielsson K, Johansson ALV. The risk of breast and gynecological cancer in women with a diagnosis of infertility: A nationwide populationbased study. Eur J Epidemiol. 2019;34:499-507.

6. Li YR, Tang YX, Qiu CX, Lin QY, Xie CJ, Zhou MY et al. Analysis of common gynecological diseases in 1142 married female workers. Zhonghua Lao Dong Wei Sheng Zhi Ye Bing Za Zhi. 2019;37:785-8.

7. Autenshlyus AI, Studenikina AA, Bernado AV, Mikhailova ES, Proskura AV, Sidorov SV et al. Assessment of the cytokine-producing resource of tumor biopsy samples from patients with invasive carcinoma of no special type and with non-malignant breast diseases. Biomed Khim. 2019;65:418-23.

8. Luo WQ, Huang QX, Huang XW, Hu HT, Zeng FQ, Wang W. Predicting breast cancer in Breast Imaging Reporting and Data System (BI-RADS) Ultrasound category 4 or 5 lesions: a nomogram combining radiomics and BI-RADS. Sci Rep. 2019;9:11921.

9. Zhang F, Jin L, Jia C, Shi Q. The role of contrastenhanced ultrasound in the diagnosis of malignant non-mass breast lesions and exploration of diagnostic criteria. Br J Radiol. 2021;94:1120.

10. Alikhassi A, Esmaili Gourabi H, Baikpour M. Comparison of inter- and intra-observer variability of breast density assessments using the fourth and fifth editions of Breast Imaging Reporting and Data System. Eur J Radiol Open. 2018;5:67-72.

11. Lee CI, Chen LE, Elmore JG. Risk-based breast cancer screening: implications of breast density. Med Clin North Am. 2017;101:725-41.

12. Boyd NF, Rommens JM, Vogt K, Lee V, Hopper JL, Yaffe MJ et al. Mammographic breast density as an intermediate phenotype for breast cancer. Lancet Oncol. 2005;6:798-808.

13. Holick MF. Medical progress: Vitamin D deficiency. N Engl J Med. 2007;357:266-81.

14. Gabaj NN, Unic A, Miler M, Pavicic T, Culej J, Bolanca I et al. In sickness and in health: Pivotal role of vitamin D. Biochem Med . 2020;30:1-13.

15. Cranney A, Horsley T, O'Donnell S, Weiler H, Puil L, Ooi $\mathrm{D}$ et al. Effectiveness and safety of vitamin $\mathrm{D}$ in relation to bone health. Evid Rep Technol Assess. 2007;1.

16. Boeke CE, Tamimi RM, Berkey CS, Colditz GA, Giovannucci E, Malspeis S et al. Adolescent dietary vitamin $\mathrm{D}$ and sun exposure in relation to benign breast disease. Cancer Causes Control. 2015;26:11817.

17. Garland CF, Gorham ED, Mohr SB, Grant, WB, Giovannucci E L, Lipkin M et al. Vitamin D and prevention of breast cancer: Pooled analysis. J Steroid Biochem Mol Biol. 2007;103:708-11.
18. Lopes N, Paredes J, Costa JL, Ylstra B, Schmitt F. Vitamin D and the mammary gland: A review on its role in normal development and breast cancer. Breast Cancer Res. 2012;14.

19. Erdfelder E, FAul F, Buchner A, Lang AG. Statistical power analyses using G*Power 3.1: Tests for correlation and regression analyses. Behav Res Methods. 2009;41:1149-60.

20. Faul F, Erdfelder E, Lang AG, Buchner A. G*Power 3: A flexible statistical power analysis program for the social, behavioral, and biomedical sciences. Behav Res Methods. 2007;39:175-91.

21. Nielsen M, Christensen L, Andersen J. Contralateral cancerous breast lesions in women with clinical invasive breast carcinoma. Cancer. 1986;57:897-903.

22. Sappino AP, Skalli O, Jackson B, Schürch W, Gabbiani G. Smooth-muscle differentiation in stromal cells of malignant and non-malignant breast tissues. Int J Cancer. 1988;41:707-12.

23. de La Puente-Yagüe M, Cuadrado-Cenzual MA, Ciudad-Cabañas MJ, Hernández-Cabria M, ColladoYurrita L. Vitamin D: and its role in breast cancer . Kaohsiung J Med Sci. 2018;34:423-7.

24. Welsh JE. Vitamin D and breast cancer: Past and present. J Steroid Biochem Mol Biol. 2018;177:15-20.

25. Khatun A, Fujimoto M, Kito H, Niwa S, Suzuki T, Ohya S. Down-regulation of $\mathrm{Ca} 2+$-activated $\mathrm{K}+$ channel KCa1.1 in human breast cancer MDA-MB453 cells treated with vitamin $\mathrm{D}$ receptor agonists. Int J Mol Sci. 2016;17.

26. Simboli-Campbell M, Narvaez CJ, Tenniswood M, Welsh JE. 1,25-Dihydroxyvitamin D3 induces morphological and biochemical markers of apoptosis in MCF-7 breast cancer cells. J Steroid Biochem Mol Biol. 1996;58:367-76.

27. Høyer-Hansen M, Bastholm L, Mathiasen IS, Elling F, Jäättelä M. Vitamin D analog EB1089 triggers dramatic lysosomal changes and Beclin 1-mediated autophagic cell death. Cell Death Differ. 2005;12:1297-309.

28. Manson JE, Mayne ST, Clinton SK. Vitamin D and prevention of cancer ready for prime time? $\mathrm{N}$ Engl J Med. 2011;364:1385-7.

29. Krishnan A V, Feldman D. Mechanisms of the anticancer and anti-inflammatory actions of vitamin D. Annu Rev Pharmacol Toxicol. 2011;51:311-36.

30. Bikle D. Nonclassic actions of vitamin D. J Clin Endocrinol Metab. 2009;94:26-34.

31. Flanagan L, Packman K, Juba B, O'Neill S, Tenniswood M, Welsh J. Efficacy of Vitamin D compounds to modulate estrogen receptor negative breast cancer growth and invasion. J Steroid Biochem Mol Biol. 2003;84:181-92.

32. Jiang X, Dimou NL, Al-Dabhani K, Lewis SJ, Martin RM, Haycock PC et al. Circulating Vitamin D concentrations and risk of breast and prostate cancer: A Mendelian randomization study. Int J Epidemiol. 2019;48:1416-24. 
33. Voutsadakis IA. Vitamin D baseline levels at diagnosis of breast cancer: A systematic review and metaanalysis. Hematol Oncol Stem Cell Ther. 2021;14:1626.

34. Nazari SS, Mukherjee P. An overview of mammographic density and its association with breast cancer. Breast Cancer. 2018;25:259-67.

35. Boyd NF, Rommens JM, Vogt K, Lee V, Hopper JL, Yaffe MJ et al. Mammographic breast density as an intermediate phenotype for breast cancer. Lancet Oncol. 2005;6:798-808.

36. Brisson J, Diorio C, Mâsse B. Wolfe's parenchymal pattern and percentage of the breast with mammographic densities: redundant or complementary classifications?. Cancer Epidemiol Biomarkers Prev. 2003;12:728-32.

37. Hunter A. Mammographic density: The risk and detection of breast caner. Journal of Biolaw and Business. 2007;10:60-1.

38. Fletcher SW, Elmore JG . Mammography screening for breast cancer. Med Lett Drugs Ther. 1980;22:534.

39. Boyd NF, Dite GS, Stone J, Gunasekara A, English DR, McCredie MRE et al. Heritability of mammographic density, a risk factor for breast cancer. N Engl J Med. 2002;347:886-94.

40. Boyd NF, Martin LJ, Bronskill M, Yaffe MJ, Duric N, Minkin S. Breast tissue composition and susceptibility to breast cancer. J Natl Cancer Inst. 2010;102:122437.

41. Bell RJ. Mammographic density and breast cancer screening. Climacteric. 2020;23:460-5.

42. Wood ME, Liu H, Storrick E, Zahrieh D, Le-Petross $\mathrm{HC}$, Jung $\mathrm{SH}$ et al. The influence of vitamin $\mathrm{D}$ on mammographic density: Results from CALGB 70806 a randomized clinical trial. Cancer Prev Res. 2021;14:753-62.

43. Brisson J, Bérubé S, Diorio C, Mâsse B, Lemieux J, Duchesne $\mathrm{T}$ et al. A randomized double-blind placebo-controlled trial of the effect of Vitamin D3 supplementation on breast density in premenopausal women. Cancer Epidemiol Biomarkers Prev. 2017;26:1233-41.

44. Duma N, Croghan I, Jenkins S, Vachon C, Neal L, Ghosh $\mathrm{K}$ et al. Assessing Vitamin D and mammographic breast density in Alaskan women. Clin Pract. 2020;10:89-92 